\title{
Biodiversity of Canadian forests: Current status and future challenges
}

\author{
by T.J.B. Boyle
}

Biodiversity is a concept covering all levels of biological organization, including genes, species, and ecosystems. Few estimates of levels of biodiversity in Canadian forests have been made. It is likely that, in general, species and ecosystem diversity do not match those in forests of more southerly latitudes, but genetic diversity is probably comparable. Although conservation activities both within and outside the natural surroundings of a species are already extensive, further efforts are justified and the effectiveness of current efforts should be demonstrated.

The impact of human disturbances on forest biodiversity must be assessed. Inappropriate forest harvesting operations can lead to habitat fragmentation and loss of ecosystem integrity. Revision of forest management systems may be required to conserve biodiversity, but comprehensive and integrated research programmes must be developed in different forest regions to provide the necessary scientific information which is currently lacking.
La diversité biologique concerne tous les niveaux d'organisation biologique, tant les gènes et les écosystèmes que les espèces. Peu d'estimations des niveaux de biodiversité dans les forêts canadiennes ont été tentées. La diversité des espèces et des écosystèmes y est probablement moins élevée que dans les forêts situées plus au sud, mais la diversité génétique y est sans doute comparable. Même si les activités de conservation in situ et $e x$ situ sont déjà considérables, des efforts supplémentaires sont justifiés, et il importe de faire voir les résultats déjà obtenus.

Les répercussions des perturbations d'origine humaine sur la biodiversité forestière doivent être évaluées. Une exploitation mal planifiée des forêts peut entraîner la fragmentation des habitats et altérer l'intégrité des écosystèmes. Une révision des systèmes d'aménagement des forêts pourrait être nécessaire pour assurer la protection de la biodiversité. Dans cette perspective, de vastes programmes intégrés de recherche doivent être réalisés dans différentes régions forestières pour obtenir l'information scientifique manquante dont on a besoin.

\section{Introduction}

Without doubt, one of the issues that will have the greatest impact on forestry practices and the forests of the future is the conservation of biodiversity. In many cultures, the original historical role of foresters was to protect the forest and the wildlife it contained. Despite this, there is considerable unease in the modern forestry community about the concept of biodiversity and the consequences of its loss or of the actions required for its conservation. The weight of public opinion is firmly in favour of conserving biodiversity, as is demonstrated by recent events in the Pacific Northwest of the United States concerning the preservation of the northern spotted owl (Strix occidentalis), and its coverage in scientific (Heilman 1990) and popular publications (Findley 1990, Watts 1991). Beyond such regional issues, however, the nations of the world recently negotiated a legally binding international treaty for the conservation of biodiversity on a global scale. Really, it is irrelevant to ask the question that forms the title of this symposium: "Should we be concerned?". We have to be concerned, we have no choice.

Much of the uncertainty surrounding biodiversity derives from a lack of understanding of the subject, encapsulated in such questions as: what is biodiversity, how is it measured, and what value should be applied to it? Although it is not the purpose of this paper to give direct answers to such questions, in discussing the biodiversity of Canadian forests it is necessary to define biodiversity, and provide at least a brief outline of its measurement and how it is valued.

\footnotetext{
Science and Sustainable Development Directorate, Forestry Canada, Ottawa, Ontario K1A 1 G5.

Prepared for the symposium "Maintaining biodiversity - Should We Be Concerned?" 23 rd Meeting of the Canadian Tree Improvement Association, Ottawa, Ontario, 19 August 1991.
}

\section{Definition}

A variety of definitions have been offered for the concept of biodiversity. All of them attempt to capture essentially the same ideas, with varying degrees of clarity and succinctness. Perhaps the best, and most widely accepted definition was proposed by the U.S. Government's Office of Technology Assessment (U.S. Congress, Office of Technology Assessment 1987), which stated that:

"Biological diversity refers to the variety and variability among living organisms and the ecological complexes in which they occur. Diversity can be defined as the number of different items and their relative frequency. For biological diversity, these items are organized at many levels, ranging from complete ecosystems to the chemical structures that are the molecular basis of heredity. Thus, the term encompasses different ecosystems, species, genes and their relative abundance"'.

This definition emphasises the two main points concerning biodiversity: firstly that it comprises all levels of biological organization, from genes through to ecosystems, and secondly, that it refers not only to numbers but also to frequencies. Thus, the reduction in frequency of genes, species, or ecosystems constitutes a loss in biodiversity. It is also important to note that biodiversity may be characterized in many other ways, for example in terms of population, or sub-species diversity, temporal, structural and functional diversity (Franklin 1988), or trophic diversity (Odum 1984).

Diversity can also be considered at different scales. For example, alpha species diversity is defined as the number of species in a given community, site type, or ecosystem. Beta species diversity is a measure of the extent to which species representation changes spatially over site types or ecosystems in a larger landscape unit. Gamma diversity, sometimes termed landscape diversity, reflects the similarity in species 
composition on the same site types in different landscape units (Whittaker 1960; Cody 1975).

\section{Measurement}

The measurement of biodiversity is analogous to the measurement of genetic variation, which constitutes the lowest level of biodiversity. The simplest assessment of genetic variation involves counts of alleles, which lead to such measures as the number of alleles per locus, and the proportion of polymorphic loci. Similarly, species counts constitute the most commonly reported assessment of species diversity.

The problem with counts, however, is that they fail to take account of the frequency of types, which is an essential component of the definition given above. In the analysis of genetic variation, therefore, indices such as expected heterozygosity and the effective number of alleles are used to incorporate information on frequencies. The same approach can be used at the species level. Two indices that are commonly proposed for measuring species diversity are Shannon's index and Simpson's index (Patil and Taillie 1982; Swindel et al. 1991). Indeed, these can also be used for measuring genetic variation.

Pielou (1977) proposed three conditions that should be satisfied by a measure of diversity. These were that:

- the index should be maximised, for a given number of species (alleles, ecosystems), when the number of individuals of each species are equal

- with equal numbers of individuals for each species, a system with more species should have a larger index

- if a community can be classifed into sub-classes, the index should be additive over the sub-classes.

Patil and Taillie (1982) added a fourth condition:

- as rarer species become more abundant at the expense of more common species, the index should increase. Simpson's index does not satisfy the third condition, whereas Shannon's index satisfies all four. The mathematical characteristics of the two indices also differ. Simpson's index is more sensitive to changes in common species, whereas Shannon's index is affected by changes in rare species (Peet 1974).

Because indices reflect both numbers and frequency, the contribution of each to a given index value is not apparent. Additional information can be gained from the calculation of "evenness"' in representation of the units being studied. More complex methods for comparison of diversity in different communities have also been developed (Swindel et al. 1987). The measurement of ecosystem diversity can utilize the same methods, but it requires the classification of ecosystems, which is more complex than the identification of species or alleles (Pielou 1977).

Beta diversity can be quantified in terms of the percentage similarity among samples (Whittaker 1972). The pattern of change in beta diversity along an environmental gradient can then be examined using regression techniques (Christensen and Peet 1984). Magurran (1988) provides a thorough discussion of many measurement methods for both alpha and beta diversity.

\section{Value}

The value of biodiversity is a topic that has received widespread attention (Ehrenfeld 1988; Hanemann 1988; Norton 1988; Randall 1988; Barbier et al. 1991; Dixon and Sherman
1991; McNeely and Dobias 1991; Randall 1991; Tobias and Mendelsohn 1991). Many types of value can be applied to biodiversity, including immediate economic value, opportunity value, existence value, spiritual value, and protection value. Of these the first two, dealing with the current direct economic value of the resource and the possible future value, are of great importance. The recent discovery of significant medicinal properties of an extractive from the bark of the previously commercially insignificant western yew (Taxus brevifolia Nutt.) emphasises the value of conserving biodiversity. It is interesting to note, however, that in Thailand, the existence value allocated by Thais to one of their National Parks due solely to the presence of wild elephants (over and above the tourist value) amounted to about $\$ 6$ million, as indicated by an economic analysis (Dixon and Sherman 1991).

A major problem with valuing biodiversity is that many of the benefits are non-quantifiable in monetary terms. For example, the maintenance of functioning ecosystems and the enhancement of the ability to adapt to future climate change are two facets of conserving biodiversity for which a value cannot easily be calculated (Cleland and Scott 1990; Probst and Crow 1991).

\section{Issues Affecting Biodiversity of Canadian Forests}

\section{Status of Biological Diversity}

Despite the weaknesses already noted in using species counts as an indication of biodiversity, they remain the most oft-quoted criterion for comparison. There are an estimated 300,000 species of animals, plants, and microorganisms in Canada (Mosquin and McAllister 1991). Bunnell (1990) reports that $76 \%$ of Canadian terrestrial mammals and $60 \%$ of Canada's breeding bird species are forest dwelling. Making the rash assumption that these two groups are representative of all living organisms, it may be conservatively estimated that about 200,000 species are found in Canada's forests. Of these, less than half have been described (Mosquin and McAllister 1991).

Estimates of species diversity in tropical forests tend to be an order of magnitude greater than those for temperate and boreal forests (Gentry 1986; Myers 1988), leading to the obvious conclusion that alpha species diversity in northern latitudes is comparatively low. Some authors, for example, Kimmins (1991), have suggested, however, that if soil microorganisms are considered, the generally poorer tropical forest soils may support fewer species than temperate and boreal forest soils.

This diversity of species is not, of course, evenly distributed structurally or spatially. One of the largest genera of trees in Canada is the maples, with 10 native species (Hosie 1979), whereas 21 species of the moss genus Dicranum are found in Ontario and Quebec alone (Bellolio-Trucco and Ireland 1990). Generally speaking, there is a gradient in species diversity from north to south, with exceptional areas of diversity in southern Ontario, and southern and western British Columbia. In more than 2 million ha of the boreal forest zone in Canada, only 38 species of trees are found, compared with 79 species in the much more restricted Carolinian forest zone. Similarly, the numbers of mammalian species in Canada tend to increase from around 30 at the treeline, to about 60 at the Canada-U.S. border, with up to 80 in southern British Columbia (Simpson 1969). 
Beta species diversity is related to both ecosystem diversity, discussed below, and structural diversity. Clearly, beta diversity is greater in landscapes having steep environmental gradients, such as British Columbia, than in landscapes having more subtle gradients, such as northern Ontario. Beta diversity also tends to be greater for those groups of organisms for which large species numbers and intense competition result in narrow ecological niches. For example, Erwin (1988) found only an $8.7 \%$ overlap in 126 species of canopy dwelling beetles collected in plots separated by only $50 \mathrm{~m}$ in tropical Peru. Although not reported, beta diversity of mammals at such a small scale would be much lower, and beta diversity of trees at the same scale would be almost meaningless.

The Committee on the Status of Endangered Wildlife in Canada (COSEWIC) lists 195 species of animals and plants as being vulnerable, threatened, endangered, or extirpated in Canada in 1990 (Canadian Wildlife Service 1990). Of these, six are tree species: the cucumber-tree (Magnolia acuminata L.), American chestnut (Castanea dentata [Marsh.] Borkh.), blue ash (Fraxinus quadrangulata Michx.), Kentucky coffee-tree (Gymnocladus dioicus [L.] K. Koch), dwarf hackberry (Celtis tenuifolia Nutt.), and hoptree (Ptelea trifoliata L.). None of these species is in danger of extinction; their status in Canada results merely from the near coincidence of their northern range boundary with the Canada-U.S. border, in the Carolinian forest zone. It may be argued that the status of these species on a national basis is of no greater concern than the status of (for example) white pine (Pinus strobus L.) in Newfoundland or parts of northern Ontario.

Many woodland species of animal, bird, and fish are also on the endangered species list. Some of these, in contrast to the endangered tree species, are not represented by large populations elsewhere. For example, the woodland caribou has already been extirpated in many parts of Canada, and is threatened elsewhere as a result of overhunting, habitat loss, and predator pressure (Van Tighem 1990). Organizations such as the Alberta Wilderness Association are contributing to conservation of the caribou and other endangered species by generating public support for habitat conservation projects.

At the level of genetic diversity, the multitude of isoenzyme studies that have been conducted on thousands of species in the past few decades have indicated that tree species contain relatively high levels of genetic diversity, and that boreal species are no less variable than tropical species (Hamrick et al. 1979, 1981; Hamrick and Loveless 1989). For many Canadian tree species, there is substantial genetic variation among individuals within populations, and correspondingly low levels of differentiation among populations (Bousquet et al. 1987; El-Kassaby 1990; Yeh 1981). This finding has been interpreted as being the result of high outcrossing rates, long generations, effective gene flow, and high fecundity (Hamrick 1982). Similarly, genetic diversity in non-woody forest plants tends to correspond with these life-cycle criteria. For example, a sub-species of a highly outcrossing fern, Gymnocarpium dryopteris (L.) found in British Columbia, maintains high levels of genetic diversity within populations, and population differentiation $\left(\mathrm{F}_{\mathrm{ST}}=0.108\right)$ is only modest (Kirkpatrick et al. 1990). Population differentiation in self-sterile diploid blueberry
(Vaccinium sect. Cyanococcus) was also found to be typical of outcrossing species (Bruederle et al. 1991). A comparison of population differentiation in several species of lichen in eastern Canada indicated that asexual species of lichens are arranged in far more distinct populations than sexual species (Hageman and Fahselt 1990).

Despite the apparent importance of life history characteristics in determining the level and pattern of genetic diversity in forest plants, there are also exceptions. Red pine (Pinus resinosa Ait.) and western red cedar (Thuja plicata Donn) exhibit no detectable allozyme variation (Fowler and Morris 1977; Copes 1981; Simon et al. 1986). In the United States, population differentiation in honey locust (Gleditsia triacanthos L.), which is found in southwestern Ontario, amounted to only about $6 \%$ of total variation, even though the species is insect pollinated and produces heavy, animal dispersed seed (Schnabel and Hamrick 1990).

Typically, vertebrates have lower levels of genetic diversity than invertebrates, which in turn are less heterozygous than plants (Nevo 1978). Because animals are more mobile than plants, differentiation tends to be detectable only over much larger areas than for plants (Liu and Godt 1983). Mobility also increases the area over which a founder effect may apply. For example, the entire moose (Alces alces) population of Newfoundland is believed to be derived from five animals introduced to the island in 1906.

An assessment of ecosystem diversity first requires ordination and classification of the ecosystems (Pielou 1977). Ecosystem classification has received a lot of attention in Canada, with systems having been developed in each province (Corns 1992, MacKinnon et al. 1992; Sims and Uhlig 1992). The biogeoclimatic ecosystem classification (BEC) system of British Columbia, which has been adapted for use in Alberta, is a hierarchical system that integrates ecosystem variation at regional and local levels and over time. For forest management purposes, "site units" based on environmental characteristics such as moisture and nutrient status are identified at the local level, and used for developing silvicultural prescriptions, for range management and for integrating recreation into multiple-use management (MacKinnon et al. 1992).

The Forest Ecosystem Classification (FEC) system of Ontario is a partially hierarchical system that is similar to the BEC of British Columbia (Sims and Uhlig 1992). Originally developed for silvicultural prescriptions, it has also been used for analysing deer food requirements (Racey et al. 1989) and bird habitat preferences (Welsh 1991). In discussing future challenges for the FEC system in Ontario, Sims and Uhlig (1992) identified research on biodiversity, together with developing an understanding of ecosystem processes and functions, the ecological properties of old-growth forests, and pathways for vegetational succession as requiring particular emphasis.

A system for classifying Canada's forests was developed by Rowe (1972), who recognized eight "forest regions", subdivided into 90 "forest sections". Other resource sectors in Canada also developed systems to suit their own needs, so in an effort to develop some degree of consistency in ecosystem classification across the country, a hierarchical biophysical system has been designed by the Canadian Committee on Ecological Land Classification. The system recognizes 15 “ecozones", 45 “ecoprovinces", 177 "ecoregions" 
and 5428 "ecodistricts". The ecoregions provide a scale of detail that is both meaningful and manageable on a national scale, and are now widely used by Environment Canada for data base and other applications (Turner et al. 1992).

However, the quantification of habitat or ecosystem diversity has received far less attention than species or genetic diversity (Christensen and Peet 1984). Also, the frame of reference for ecosystem diversity must be larger than the ecosystem itself, and will therefore usually be completely arbitrary (e.g. provincial). Nevertheless, some studies of ecosystem diversity have been conducted (Romme 1982). In order to enable comparison of measurements of ecosystem diversity, however, the ordination and classification procedures must be identical, or at least comparable, and this is rarely the case.

\section{Conservation of Biodiversity}

The various factors that led to the development of conservation biology as a scientific discipline, and of the conservation ethic as a social phenomenon, are reviewed by Soulé (1986). Undoubtedly the most powerful factor is the "extinction spasm" (Myers 1988) that has resulted from nonsustainable use of natural resources, which in turn is a consequence of massive human population growth and various social ills such as poverty.

A survey of genetic conservation activities for tree species in Canada was conducted, covering both in situ and $e x$ situ conservation efforts. The in situ conservation activities (parks and other reserves) account for most of the species conservation and, necessarily, all of the ecosystem conservation. Federal and provincial governments, industry and universities were asked to report, for 1990-91, existing activities related to conservation (Table 1).

For the whole of Canada, an estimated $4 \%$ of productive forest land is categorized as having a highly protected status: land in National Parks, ecological reserves, and other areas in which forest management operations are prohibited (Lowe 1991). This percentage corresponds with the estimate of protected areas by the World Commission on the Environment and Development (WCED); their call for a tripling of protected areas (World Commission on the Environment and Development 1987) led to the federal government's target of protecting $12 \%$ of Canada's land area.

The degree of proțection afforded by different categories of reserves and parks is highly variable. For example, logging activities are currently permitted in Wood Buffalo National Park, and the degree of protection in provincial parks in Ontario varies widely. The World Conservation Union (IUCN) utilizes five categories of protection in classifying conservation areas (World Conservation Union 1990), and these categories are now recorded in the National Conservation Area Data Base created by Environment Canada and the Canadian Council on Ecological Areas.

Outside of conservation areas, an additional $18 \%$ of productive forest is classified as being under "policy constraint" (Lowe 1991). This area includes land that will not be harvested due to legislative or policy guidelines, such as buffers along watercourses, and land that the owner has decided not to harvest, for example, land in the Carolinian zone owned by conservation agencies or covered by management agreements with conservation agencies. It should also be noted that $45 \%$ of forested land in Canada is classified

\begin{tabular}{lccl}
\hline \multicolumn{4}{l}{ Table 1. Conservation of Canadian forest biodiversity } \\
\hline Activity & Number & Area (ha) & Other details \\
\hline 1. National Parks & 34 & 5.1 million & Forested land \\
2. Other reserves & 3,100 & 38.5 million & Forested land \\
3. Reserved stands & 458 & 42,900 & \\
4. Seed production areas & 228 & 8,200 & \\
5. Seed Orchards (seed) & 63 & 1,875 & 28,400 families \\
(clonal) & 78 & 1,100 & 13,800 clones \\
6. Clonal archives & 100 & 309 & 43,100 clones \\
7. Provenance tests & 202 & 950 & 14,500 provenances \\
8. Seed bank (seed lots) & 33,500 & & 3.15 billion seed. \\
& & & plus 260.000 kg \\
\hline
\end{tabular}

as non-productive, and an additional small percentage of productive forest is not currently economically accessible (Lowe 1991).

The foregoing does not imply, however, that the target of $12 \%$ of protected land has been met or does not need to be pursued. Under the federal government's Green Plan, Forestry Canada is promoting the extension of the forested ecological reserve network to ensure adequate representation of all forest ecosystems in protected areas. Improvements to the National Conservation Area Data Base will also be undertaken as part of this programme.

A lot of literature has been devoted to the topic of the design and management of ecological reserves (for reviews, see Harris 1984, Hunter 1990). The effectiveness of ecological reserves will be affected by their size, shape, and distribution, and by the management of surrounding lands. Small reserves will conserve fewer species than larger ones, approximately circular reserves will minimize edge effects, and isolated, scattered reserves will not be as effective as closely spaced or linked reserves. Sensitive management of the area surrounding the reserve can also increase its value. At present, these considerations and others have received little attention in the establishment of forest ecological reserves in Canada. For this reason, the target figure of $12 \%$ may be less important than the choice and design of reserves, and the enlightenment of forestry practices outside the reserves.

The categories of ex situ conservation activities reported in the survey covered seed banks, clonal archives, seed orchards and provenance tests. Although many of these activities were not initiated for the express purpose of genetic conservation, they nevertheless achieve this purpose. In seed banks across Canada, 33,500 forest tree seedlots are in storage, most representing open-pollinated families. These seedlots comprise over 3.1 billion seeds, with an additional 260 tonnes of seed in storage for which numbers of seeds were not reported. The total forest tree seed in storage in Canada can therefore be conservatively estimated at about 5 billion seeds, sufficient to reforest 2.5 million ha.

More than 28,000 families are represented in more than 1800 ha of seedling seed orchards across the country. Clonal seed orchards contain almost 14,000 clones and cover over 1000 ha, while 43,100 clones are preserved in clonal archives (many of which are also represented in seed orchards). In New Brunswick, the entire annual requirements for planting stock of some major species are already produced from seed orchards, while in British Columbia $47 \%$ of the coastal Douglas fir (Pseudotsuga menziesii [Mirb.] Franco) stock is of seed orchard origin. The use of seed orchard seed holds 
the potential for reducing genetic diversity of the resultant forests. At the early stages of tree improvement, which is the limit of genetic improvement programmes thus far in Canada, the inclusion of large numbers of families and/or clones in seed orchards limits the decrease in genetic diversity. Although the peak period of seed orchard and provenance test establishment has passed (Ying and Morgenstern 1988), such activities will continue, and represent an enormous capital of ex situ genetic conservation.

\section{Impacts of Forest Management on Biodiversity}

Much of the concern with problems of species and genetic conservation stems from the impact of human activities on natural ecosystems, and non-sustainable exploitation of such ecosystems. It is only natural, therefore, that the impact of various forestry operations on forest ecosystems has been the subject of much debate and not a little acrimony. Recent events in the Carmanagh Valley, on South Moresby Island and various other areas in British Columbia, and near Temagami in northern Ontario have received much public attention and, in some cases, resulted in court battles. As well, forest management operations in the boreal and Great Lakes-St. Lawrence forest zones of Ontario have been the subject of a seemingly interminable and extremely expensive "class environmental assessment" process.

The status of "old-growth" forest, and the effect of harvesting and the habitat fragmentation resulting from harvesting of the old-growth ecosystem, has been the subject of great debate both in Canada and the United States. The most well-known case is that of the northern spotted owl in the Pacific Northwest of the United States. Three characteristics of the spotted owl have led to its prominent status: its apparent dependence on an old-growth forest habitat (Carey 1985), its very large home range requirements (Sisco and Gutierrez 1984), and its demographic fragility (Dawson et al. 1987). These characteristics demand that if survival of the species is to be ensured, a very conservative habitat management system involving the preservation of large areas of old-growth forest must be undertaken. An Interagency Science Committee was formed to design a management system for spotted owls, and it recommended the establishment of a network of conservation areas averaging about 25,000 ha and separated by no more than $20 \mathrm{~km}$ (Wood 1991). In this instance, the spotted owl is fulfilling the role of an "indicator species". The owl itself is rather less important than the ecosystem it represents. The marbled murrelet (Brachyramphus marmoratus) appears to perform a similar function as an indicator of old-growth ecosystem conditions in the coastal forest of British Columbia (Rodway et al. 1991).

Clearcutting obviously causes enormous changes to the ecosystem, with dramatic consequences to many organisms. For this reason, clearcutting has been the target of environmental groups and the subject of much research. The effects on vertebrates of clearcutting is highly variable. Some species, for example moose, benefit from a mosaic of food and cover habitats, such as might result from a series of relatively small clearcuts (Timmermann and McNichol 1988; Payne et al. 1988). Of the common fur-bearing mammals in the boreal forest zone of Ontario, only the marten (Martes americana) appears to be reliant on old-growth forest (Thompson 1988, 1991). Most other fur-bearing species reach peak densities in early or mid-successional habitats, mainly in response to the buildup of prey species (Thompson 1988).

Although studies have demonstrated a significant decrease in some species of songbirds following clearcutting, other species are dependent on early successional stages (Welsh 1988, 1991). The passerines constitute the dominant family of birds in the boreal forest, and although some species are no longer present after clearcutting, others take their place, such that overall species diversity of all bird species is virtually unchanged (Welsh and Fillman 1980). Many species of songbirds are clearly dependent on specific forest ecosystems, as well as on specific successional stages. A study of species abundance in northern Ontario in relation to the Forest Ecosystem Classification system demonstrated quite narrow ecosystem preferences for many species (Welsh 1991). Maintaining species diversity for birds and other fauna therefore requires a continuing supply of forest ecosystems in various successional stages.

In the Nantahala national forest of North Carolina, a comprehensive series of studies has been conducted on the response of many organisms to clearcutting (Bruce and Boyce 1984). No equivalent research has been undertaken in Canada, but the forest type at Nantahala is very similar to some of the southern sections of the Great Lakes-St. Lawrence forest zone (Rowe 1972), so the results may have some relevance to Canadian conditions. Using Shannon's index to measure species-within-genus and genus diversity for carabid beetles, spiders, and centipedes, clearcutting usually reduced genus diversity but species-within-genus diversity invariably increased, largely due to more equal species abundances (Bruce and Boyce 1984). Small mammals, birds, and salamanders were also studied, and they demonstrated highly variable responses to clearcutting.

Niese and Strong (1992) compared results of various cutting methods in "northern" hardwood stands of the Lake States forest zone in Wisconsin, in terms of both economic return and tree species diversity. Overall diversity, as measured by Shannon's index, was greater in plots managed by clearcutting and shelterwood than in the control, after 40 years of management. Shelterwood management yielded a greater economic return than clearcutting. Also, although initial saw timber volume was greatest from clearcutting, the total saw timber volume from repeated harvests under shelterwood management resulted in greater yields over the period of the study. Diameter-limit cutting regimes yielded high initial economic returns, but at a substantial cost in terms of species diversity, tending to result in pure sugar maple (Acer saccharum Marsh.) stands. Increased species diversity of woody species a few years after clearcutting has also been reported in southern pine forests (Swindel et al. 1984).

Obviously, the impact of clearcutting is not a simple reduction in species diversity, but rather a differential effect, with some old-growth dependent species of plants and animals being lost from the system, presumably until suitable environmental conditions are restored. However, the scale and pattern of clearcuts are also vitally important in determining the response of different species to disturbance. The resultant spatial heterogeneity and fragmentation of the landscape have a significant impact on species diversity and abundance. Fragments smaller than a species' home range will result in 
a reduction in abundance of that species, or its complete elimination. The ecosystem itself may then be threatened with destruction. Research on boreal fragmentation in Sweden has demonstrated that 1 ha reserves that are required by law are composed entirely of edge habitat, and therefore do not function as forest ecosystems (Dr. Per-Anders Esseen, personal communication). Because edge effects penetrate some distance into the remaining forest, even a low intensity of clearcutting can cause substantial habitat fragmentation (Hansen et al. 1991).

Concern with forest fragmentation and the resultant extensive edge effects, together with a recognition of the importance of structural diversity in forests, has led to the development of a philosophy termed "The New Forestry" in the Pacific Northwest of the United States (Franklin 1989; Maser 1990; Hansen et al. 1991). Part of this philosophy calls for large cut blocks, to minimize edge effects. Large trees, snags, and fallen logs are retained on the harvested area to provide habitat for cavity-nesting birds, amphibians, fungi, and other microorganisms.

One defense of clearcutting has been that it mimics natural processes, such as fire, in some ecosystems. However, a study of natural and human disturbances in northern Ontario indicated that the scale of harvesting operations was much smaller than natural events, with possible implications for abundance of "fforest interior"' bird species (Dr. D.A. Welsh, personal communication). Some environmentalists have also called for larger clearcuts, thus allowing larger contiguous areas of undisturbed forest (Eiger 1991).

The on-going debate on size and style of clearcutting is only likely to intensify in the near future. There can be no generally applicable "optimum" size of a clearcut, whether the main consideration is economics, aesthetics, habitat, or diversity. Locality, ecosystem, and topography will all affect the most desirable size of cut. Additional factors to be considered are large-scale spatial heterogeneity and the need to avoid uniformity in clearcut size (Hunter 1990; Hansen et al. 1991). Obviously, with so many factors affecting the choice of whether to clearcut and, if so, the size of cut, only an integrated programme of research in different forest types can generate the necessary information on which sensible decisions can be based.

Harvesting is not the only forest management operation affecting diversity: several others are reviewed by Hunter (1990). Of particular interest to those involved in tree improvement is regeneration, and particularly the use of genetically improved and clonal planting stock. Despite dramatic increases in annual planting programmes in recent years, only $20 \%$ of land that is harvested or lost to fires and pests each year is currently regenerated by planting (Forestry Canada 1990). Most of the planting stock still comes from "wild" collections although, as noted above, seed orchard seed is now meeting demands in some provinces. The proportion of planting stock that is clonal remains tiny, but more than a hundred hectares of experimental black spruce (Picea mariana [mill.] B.S.P.) stecklings have been planted in northern Ontario, and Quebec is undertaking a similar programme.

A typical seed orchard in Canada may consist of several hundred open-pollinated families, resulting in tens of thousands of possible inter-family pollinations. The permutations in clonal orchards may be fewer, but greater fecundity is likely to result in a more even representation of possible crosses. When temporal and spatial variation in fecundity of natural forests is considered, planting with seed orchard seed is unlikely to reduce genetic diversity of the planted species, and may increase it. Except in very simple ecosystems, however, tree species and age structure diversity is likely to be reduced as a result of site preparation and planting.

As discussed previously, however, frequency or abundance are not the only important aspects of diversity: spatial heterogeneity or pattern may also have important ecological consequences. The spatial arrangement of genetic diversity on planted sites will be completely artificial. This is of particular concern when dealing with clonal planting stock, when choices must be made as to the size and arrangement of monoclonal blocks, or clonal representation in an intimate mixture. Again, although arbitrary guidelines can be established, as has been done in Ontario, the ecological consequences of such choices can be determined only through a comprehensive programme of research.

The assumption is often made that natural regeneration guarantees maintenance of diversity. This is true only when harvesting operations mimic natural disturbances in a given ecosystem. Thus, the New Forestry style of harvesting practices, with retention of trees, snags, and logs, may adequately mimic a natural disturbance such as fire in the coastal forest. Applying exactly the same design to boreal or Great LakesSt. Lawrence forests may not be justifiable.

\section{Research on Forest Biodiversity in Canada}

The substantial differences in constitutions and land tenure systems between Canada and the United States have resulted in fewer legislative pressures in Canada to incorporate diversity issues into planning and management. As a result, research on biodiversity in Canada has lagged far behind the much more active programmes in the United States. However, current domestic and international initiatives addressing biodiversity have led to a rapid expansion in research effort devoted to diversity issues. A major impetus to such research has been the federal government's "Green Plan', released in December 1990, through which substantial sums of money have been identified to support activities related to biodiversity.

There is a long history of research in Canada on genetic diversity of commercial tree species (Boyle 1988; Magnussen and Boyle 1989), carried out largely by government (Forestry Canada and some provinces) and universities. Studies on the environmental requirements of birds and large mammals have also been frequent, as has research on ecological classification. What has been lacking in forest research in Canada, however, is a comprehensive investigation of representative forest ecosystems of the type seen for Barro Colorado Island in Panama (Terborgh 1974; Ocana et al. 1988; Hamrick and Loveless 1989), or the Andrews Experimental Forest (Franklin 1989) and the Nantahala National Forest in the United States (Bruce and Boyce 1984). In these examples, research on population genetics and dynamics of trees and other forest organisms has been coordinated by large groups of scientists.

The lack of comprehensiveness and coordination in Canada is largely due to the independence of the relevant agencies: different departments of the federal government, provincial governments, industry, and universities. The result is that 
for no ecosystem do we have estimates of genetic and species diversity for several groups of organisms, including temporal and spatial variation, and the effects of forestry practices. Without such information, scientifically tenable assessments of the impact of various human or natural events cannot be made.

\section{Conclusions}

Forest ecosystems in Canada are currently not threatened to the same extent as those in many countries that suffer from greater population pressures. However, just as the effects of deforestation become evident long before the final tree is felled, so loss of biodiversity may have significant effects even in still-functioning ecosystems. With the current and projected intensity of forest management in Canada, the impact of human disturbance on natural ecosystems is a valid concern. There is consequently an urgent need for a careful examination of existing and planned activities in four areas: conservation, management, research, and education.

\section{Conservation}

The so-called "precautionary principle" has gained almost world-wide acceptance in dealing with global environmental problems such as climate change. This principle holds that the lack of scientific proof should not be used as an excuse for inaction or, to put it another way, we should err on the side of the environment. The precautionary principle should be paramount in dealing with the biodiversity of Canadian forests. Therefore in situ conservation of representative forest ecosystems should be vigorously pursued. The federal government's target of $12 \%$ of the land area under protected status should be accompanied by careful consideration of the location and design of reserves on a landscape level, as well as research to establish whether $12 \%$ is adequate in different ecosystems. The design of management regimes for both the reserve and surrounding areas is also critical to ensure that the objectives of the reserves are met. As discussed by Gladstone and Ledig (1990), intensification of forest management on "prime" lands can contribute to conservation on a national scale.

\section{Management}

A revised philosophy of forest management in Canada is required. This does not mean merely adopting the New Forestry of the Pacific Northwest, but applying the same process of structural and functional analysis to Canadian forest ecosystems. Forest management to conserve biodiversity should be typified by the following characteristics (Cleland and Scott 1990; Probst and Crow 1991):

- Systems management at a landscape scale, emphasizing the maintenance of ecological integrity rather than a stand-by-stand approach

- Emphasis on multi-species, including human, management

- Maintenance or enhancement of spatial patterns and heterogeneity.

This type of philosophy is already applied with great success in some places in Canada. An example is Algonquin Provincial Park in Ontario, where the underlying principle of forest management is that harvesting must be supply-driven rather than demand-driven (W. Brown, personal communication). The economic assessment of forest operations should not merely consider immediate direct costs, but all costs to the ecosystem. The research of Niese and Strong (1992) has clearly demonstrated that when considered over a long time scale, clearcutting is not the most economic harvesting system in northern hardwood forests, in terms of cost, productivity, or biodiversity.

\section{Research and monitoring}

Improved conservation and management can only be achieved through supporting research. It is vitally important that coordinated and comprehensive programmes of research on forest biodiversity should be established in the major forest types of Canada, integrating work on plants and animals by ecologists, population geneticists, landscape ecologists, and economists. These research programmes must begin with thorough surveys and inventories, quantifying existing biodiversity, and be followed with an assessment of the impact of natural and human disturbances.

Because many problems and concerns are already evident, short-term research is also essential, particularly in evaluating alternative management regimes and their immediate impacts. Much could be learned from re-examining existing data sets and historical experiments which were probably not established with the objective of studying biodiversity per se, but which may yield much valuable additional information.

\section{Education}

Public interest in forest management issues is increasing (Heilman 1990). This is a fact that cannot and should not be denied or avoided. It is therefore important that the public be well educated about the issues and possible solutions. Public opinion should be guided by accurate and balanced information, which is not always available at present, either from public or private agencies.

\section{Acknowledgements}

The author gratefully acknowledges valuable comments by Dr. P.J. Burton and an anonymous reviewer on an earlier version of the manuscript.

\section{References}

Barbier, E.B., J.C. Burgess and A. Markandya. 1991. The economics of tropical deforestation. Ambio 20: 55-58. Bellolio-Trucco, G. and R.R. Ireland. 1990. A taxonomic study of the moss genus Dicranum (Dicranaceae) in Ontario and Quebec. Can. J. Bot. 68: 867-909.

Bousquet, J., W.M. Cheliak and M. Lalonde. 1987. Genetic differentiation among 22 mature populations of green alder (Alnus crispa) in central Quebec. Can. J. For. Res. 17: 219-227.

Boyle, T.J.B. 1988. Proceedings of the twenty-first meeting of the Canadian Tree Improvement Association: part 1, Truro, NS.

Bruce, R.C. and S.G. Boyce. 1984. Measurements of diversity on the Nantahala National Forest. Pages 71-85 In: J.L. Cooley and J.H. Cooley (eds.). Natural diversity in forest ecosystems: Proceedings of the workshop. Inst. Ecol., University of Georgia, Athens, GA.

Bruederle, L.P., N. Vorsa and J.R. Ballington. 1991. Population genetic structure in diploid blueberry Vaccinium section Cyanococcus (Ericaceae). Am. J. Bot. 78: 230-237. 
Bunnell, F.L. 1990. Biodiversity: What, where, why and how. Pages 29-45 In: A. Chambers (ed.). Wildlife-forestry symposium, Prince George, B.C. For. Res. Dev. Agreement Rep. 160, B.C. Ministry of Forests/Forestry Canada, Victoria, BC.

Canadian Wildlife Service. 1990. COSEWIC review. Recovery 2(1): 4-5.

Carey, A.B. 1985. A summary of the scientific basis for spotted owl management. Pages 100-114 In: R.J. Gutierrez and A.B. Carey (eds.). Ecology and management of the spotted owl in the Pacific Northwest. USDA For. Serv. Gen. Tech. Rep. PNW-185.

Christensen, N.L. and R.K. Peet 1984. Measures of natural diversity. Pages 43-56 In: J.L. Cooley and J.H. Cooley (eds.). Natural diversity in forest ecosystems: Proceedings of the workshop. Inst. Ecol., University of Georgia, Athens, GA. Cleland, D.T. and R.E. Scott. 1990. The U.S. Forest Service perspective on managing for biodiversity on federal lands. Mich. Academician 22: 355-363.

Cody, M.L. 1975. Towards a theory of continental species diversity: Bird distributions over Mediterranean habitat gradients. Pages 214-257 In: M.L. Cody and J.M. Diamond (eds.). Ecology and evolution of communities. Harvard University Press, Cambridge, MA.

Copes, D.L. 1981. Isoenzyme uniformity in western red cedar seedlings from Oregon and Washington. Can. J. For. Res. 11: 451-453.

Corns, I.G.W. 1992. Forest site classification in Alberta: Its evolution and present status. For. Chron. 68: 85-93.

Dawson, W.R., J.D. Ligon, J.R. Murphy, J.P. Myers, D. Simberloff and J. Verner. 1987. Report of the advisory committee on the spotted owl. Condor 89: 205-229. Dixon, J.A. and P.B. Sherman. 1991. Economics of protected areas. Ambio 20: 68-74.

Ehrenfeld, D. 1988. Why put a value on biodiversity? Pages 212-216 In: E.O. Wilson (Ed.). Biodiversity. Nat. Acad. Press, Washington, DC.

Eiger, N. 1991. Diversity could be the new focus for managing forests and lakes. The Great Lakes Reporter, March/April 1991:3.

El-Kassaby, Y.A. 1990. Genetic variation within and among conifer populations: Review and evaluation of methods. Pages 59-74 In: H.H. Hattemer and S. Fineschi (eds.). Biochemical markers in the population genetics of forest trees. SPB Academic Publishing, The Hague.

Erwin, T.L. 1988. The tropical forest canopy: The heart of biotic diversity. Pages 123-129 In: E.O. Wilson (ed.). Biodiversity. Nat. Acad. Press, Washington, DC.

Findley, R. 1990. Will we save our own? Nat. Geographic, 178(3): 106-136.

Forestry Canada. 1990. Forestry facts. Ottawa, Ont. Fowler, D.P. and R.W. Morris. 1977. Genetic diversity in red pine: Evidence for low genic heterozygosity. Can. J. For. Res. 7: 343-347.

Franklin, J.F. 1988. Structural and functional diversity in temperate forests. Pages 166-175 In: E.O. Wilson (ed.). Biodiversity. Nat. Acad. Press, Washington, DC.

Franklin, J.F. 1989. Toward a New Forestry. Am. Forests 95(11/12): 37-44.

Gentry, A.H. 1986. Endemism in tropical versus temperate plant communities. Pages 153-181 In: M.E. Soulé (ed.). Conservation biology. Sinauer Assoc., Sunderland, MA.
Gladstone, W.T. and F.T. Ledig. 1990. Reducing pressure on natural forests through high-yield forestry. For. Ecol. Manag. 35: 69-78.

Hageman, C. and D. Fahselt. 1990. Enzyme electromorph variation in the lichen family Umbilicariaceae: Within stand polymorphism in umbilicate lichens of eastern Canada. Can. J. Bot. 68: 2636-2643.

Hamrick, J.L. 1982. Plant population genetics and evolution. Am. J. Bot. 69: 1685-1693.

Hamrick, J.L., Y.B. Linhart and J.B. Mitton. 1979. Relationships between life history characteristics and electrophoretically detectable genetic variation in plants. Ann. Rev. Ecol. Syst. 10: 173-200.

Hamrick, J.L. and M.D. Loveless. 1989. The genetic structure of tropical tree populations: Associations with reproductive biology. Pages 129-146 In: J.H. Bock and Y.B. Linhart (eds.). The evolutionary biology of plants. Westview Press, Boulder, CO.

Hamrick, J.L., J.B. Mitton and Y.B. Linhart. 1981. Levels of genetic variation in trees: influence of life history characteristics. Pages 35-41 In: M.T. Conkle (ed.). Proc. Symp. on Isozymes of N. Am. For. Trees and For. Insects. USDA For. Serv. Gen. Tech. Rep. PSW 48.

Hanemann, W.M. 1988. Economics and the preservation of biodiversity. Pages 193-199 In: E.O. Wilson (ed.). Biodiversity. Nat. Acad. Press, Washington, DC.

Hansen, A.J., T.A. Spies, F.J. Swanson and J.L. Ohmann. 1991. Conserving biodiversity in managed forests. Bioscience 41: 382-392.

Harris, L.D. 1984. The fragmented forest. University of Chicago Press, Chicago, IL.

Heilman, P.E. 1990. Forest management challenged in the Pacific Northwest. J. For. 88(11): 16-23.

Hosie, R.C. 1979. Native trees of Canada. Fitzhenry \& Whiteside, Don Mills, ON.

Hunter, M.L. 1990. Wildlife, forests and forestry: Principles of managing forests for biodiversity. Prentice Hall, Englewood Cliffs, NJ.

Kimmins, J.P. 1991. Biodiversity: An environmental imperative. Pages 225-231 In: Proceedings of the Canadian Pulp and Paper Association Meeting, Montreal, QC.

Kirkpatrick, R.E.B., P.S. Soltis and D.E. Soltis. 1990. Mating system and distribution of genetic variation in Gymnocarpium dryopteris ssp. disjunctum. Am. J. Bot. 77: 1101-1110.

Liu, E.H. and M.J.W. Godt. 1983. The differentiation of populations over short distances. Pages 78-95 In: C.M. Schonewald-Cox, S.M. Chambers, B. MacBryde and W.L. Thomas (eds.). Genetics and conservation. Benjamin/Cummings Publ. Co., Menlo Park, CA.

Lowe, J.J. 1991. Canada's forest inventory: The sustainable commercial timber base and its growth rate. Pages 33-36 In: D.G. Brand (ed.). Canada's timber resources. For. Can. Info. Rep. PI-X-101.

MacKinnon, A., D. Meidinger and K. Klinka. 1992. Use of the biogeoclimatic ecosystem classification system in British Columbia. For. Chron. 68: 100-120.

Magnussen, S. and T.J.B. Boyle. 1989. Proceedings of the twenty-second meeting of the Canadian Tree Improvement Association: part 1, Edmonton, AB.

Magurran, A.E. 1988. Ecological diversity and its measurement. Princeton University Press, Princeton, NJ. 
Maser, C. 1990. The redesigned forest. Stoddart, Toronto, ON.

McNeely, J.A. and R.J. Dobias. 1991. Economic incentives for conserving biological diversity in Thailand. Ambio 20: $86-90$.

Mosquin, T. and D.E. McAllister. 1991. Canada's biodiversity: An inventory and analysis. Unpubl. paper, Canadian Museum of Nature.

Myers, N. 1988. Tropical forests and their species: going, going ... ? Pages 28-35 In: E.O. Wilson (ed.). Biodiversity. Nat. Acad. Press, Washington, DC.

Nevo, E. 1978. Genetic variation in natural populations: Patterns and theory. Theor. Pop. Biol. 13: 121-177.

Niese, J.N. and T.F. Strong. 1992. Economic and biodiversity trade-offs in managed northern hardwoods. Can. J. For. Res. 22 (in press).

Norton, B. 1988. Commodity, amenity, and morality: the limits of quantification in valuing biodiversity. Pages 200-205 In: E.O. Wilson (ed.) Biodiversity. Nat. Acad. Press, Washington, DC.

Ocana, G., I. Rubinoff, N. Smythe and D. Werner. 1988. Alternatives to destruction: research in Panama. Pages 370-376 In: E.O. Wilson (ed.). Biodiversity. Nat. Acad. Press, Washington, DC.

Odum, E.P. 1984. Diversity and the forest ecosystem. Pages 35-41 In: J.L. Cooley and J.H. Cooley (eds.). Natural diversity in forest ecosystems: Proceedings of the workshop. Inst. Ecol., Univ. Georgia, Athens, GA.

Patil, G.P. and C. Taillie. 1982. Diversity as a concept and its measurement. J. Am. Stat. Assoc. 77: 548-561.

Payne, D., J. McNichol, G. Eason and D. Abraham. 1988. Moose habitat management and timber management planning: Three case studies. For. Chron. 64: 270-276.

Peet, R.K. 1974. The measurement of species diversity. Ann. Rev. Syst. Ecol. 5: 285-307.

Pielou, E.C. 1977. Mathematical ecology. John Wiley \& Sons, Toronto, ON.

Probst, J.R. and T.R. Crow. 1991. Integrating biological diversity and resource management. J. For. 89(2): 12-17. Racey, G.D., J. McNichol and H.R. Timmermann. 1989. Application of the moose and deer habitat guidelines: Impact of investment. Pages 119-132 In: R.F. Calvert, B. Payandeh, M.F. Squires and W.D. Baker (eds.). Forest investment: A critical look. For. Can. Info. Rep. O-P-17.

Randall, A. 1988. What mainstream economists have to say about the value of biodiversity. Pages 217-223 In: E.O. Wilson (ed.). Biodiversity. Nat. Acad. Press, Washington, DC.

Randall, A. 1991. The value of biodiversity. Ambio 20: 64-74.

Rodway, M.S., J-P.L. Savard and H.M. Regehr. 1991. Habitat use and activity patterns of marbled murrelets at inland and at-sea sites in the Queen Charlotte Islands, British Columbia. Canadian Wildlife Service Tech. Rep. Ser. 122. Romme, W.H. 1982. Fire and landscape diversity in subalpine forests of Yellowstone National Park. Ecol. Monogr. 52: 199-221.

Rowe, J.S. 1972. Forest regions of Canada. Can. For. Serv. Publ. No. 1300.

Schnabel, A. and J.L. Hamrick. 1990. Organization of genetic diversity within and among populations of Gleditsia triacanthos (Leguminaceae). Am. J. Bot. 77: 1060-1969.
Simon, J.P., Y. Bergeron and D. Gagnon. 1986. Isozyme uniformity in populations of red pine (Pinus resinosa) in the Abitibi region, Quebec. Can. J. For. Res. 16: 1133-1135. Simpson, G.G. 1969. Species density of North American recent mammals. Syst. Zool. 13: 57-73.

Sims, R.A. and P. Uhlig. 1992. The current status of forest site classification in Ontario. For. Chron. 68: 64-76.

Sisco, C. and R.J. Gutierrez. 1984. Winter ecology of radio tagged spotted owls in Six Rivers National Forest, Humboldt Co., CA. USDA For. Serv. Six Rivers Nat. For. Final Rep. Soulé, M.E. 1986. Conservation biology and the "real world". Pages 1-12 In: M.E. Soulé (ed.). Conservation biology. Sinauer Assocs., Sunderland, MA.

Swindel, B.F., L.F. Conde and J.E. Smith. 1984. Species diversity: Concept, measurement, and response to clearcutting and site preparation. For. Ecol. Manag. 8: 11-22. Swindel, B.F., L.F. Conde and J.E. Smith. 1987. Indexfree diversity orderings: Concept, measurement and observed response to clear-cutting and site preparation. For. Ecol. Manag. 20: 195-208.

Swindel, B.F., J.E. Smith and R.C. Abt. 1991. Methodology for predicting species diversity in managed forests. For. Ecol. Manag. 40: 75-85.

Terborgh, J. 1974. Preservation of natural diversity: The problem of extinction-prone species. Bioscience 24: 715-722. Thompson, I.D. 1988. Habitat needs of furbearers in relation to logging in boreal Ontario. For. Chron. 64: 251-261. Thompson, I.D. 1991. Could marten become the spotted owl of eastern Canada? For. Chron. 67: 136-140.

Timmermann, H.R. and J.G. McNichol. 1988. Moose habitat needs. For. Chron. 64: 238-245.

Tobias, D. and R. Mendelsohn. 1991. Valuing ecotourism in a tropical rain-forest reserve. Ambio 20: 91-93.

Turner, A.M., C.D.A. Rubec and E.B. Wiken. 1992. Canadian ecosystems: A systems approach to their conservation. In : J.H.M. Willison, S. Bondrup-Nielsen, C. Drysdale, T.B. Herman, N.W.P. Munro and T.L. Pollock (eds.). Science and management of protected areas: Proceedings of an international conference, Wolfville, NS. Elsevier, Amsterdam.

U.S. Congress, Office of Technology Assessment. 1987. Technologies to maintain biological diversity. OTA-F-330, US Government Printing Office, Washington DC.

Van Tighem, K. 1990. Grey ghosts. Nature Can., Fall: 23-27.

Watts, R. 1991. Pressure builds to incorporate concept of biodiversity in management of forests. Victoria TimesColonial, 8 April 1991, page A14, Victoria, BC.

Welsh, D.A. 1988. Meeting habitat needs of non-game forest wildlife. For. Chron. 64: 262-266.

Welsh, D.A. 1991. Managing forested land for the conservation of biological diversity and the production of timber. Int. Assoc. Landscape Ecologists' Conf., Ottawa, ON (Unpubl. abstract).

Welsh, D.A. and D.R. Fillman. 1980. The impact of forest cutting on boreal bird populations. Am. Birds 34: 84-94. Whittaker, R.H. 1960. Vegetation of the Siskiyou mountains, Oregon and California. Ecol. Monogr. 30: 279-338. Whittaker, R.H. 1972. Evolution and measurement of species diversity. Taxon 21: 213-251.

Wood, G.W. 1991. Owl conservation strategy flawed. J. For. 89(2): 39-42. 
World Commission on Environment and Development (WCED). 1987. Our common future. Oxford University Press. Oxford, U.K.

World Conservation Union. 1990. A framework for the classification of terrestial and marine protected areas. Gland, Switzerland.

Yeh, F.C. 1981. Analyses of gene diversity in some species of conifer. Pages 48-52 In: M.T. Conkle (ed.). Proc. Symp. on Isozymes of N. Am. For. Trees and For. Insects. USDA For. Serv. Gen. Tech. Rep. PSW 48.

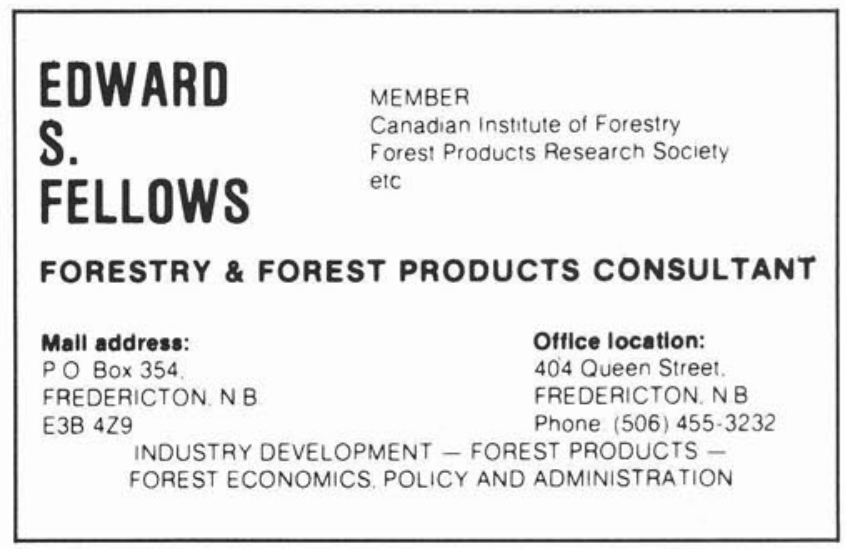

\section{ARBex FORESTRY CONSULTANTS}

TEMPERATE AND TROPICAL FORESTRY FOREST INVENTORY DESIGN AND APPLICATIONS FOREST MANAGEMENT PLANNING AND OPERATIONS FORESTRY PROGRAMMES FOR MICROCOMPUTERS
P.O. Box 5500 3439 McBean Street Richmond, Ontario KOA $2 Z 0$

Phone: (613) 838-2047 Fax:

(613) $838-5419$
(514) 282-0686 1110 Sherbrooke W. Ste. 2304

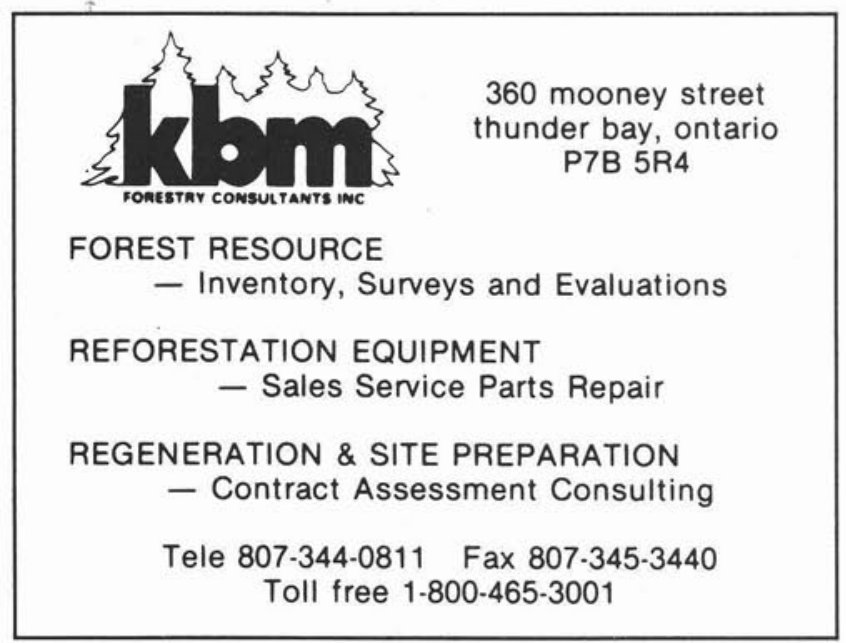

Ying, C.C. and E.K. Morgenstern. 1988. The status of provenance research in Canada. Pages 1-19 In: E.K. Morgenstern and T.J.B. Boyle (eds.). Tree Improvement progressing together. Proc. 21 st Meeting of the Can. Tree Improv. Assoc., Truro, NS.

\section{AUSTRALIA WANTS YOU ALL OCCUPATIONS Earn up to $50 \%$ more Many Extras \& Benefits \\ Call 714-573-9247 \\ General Services Center Open $8 \mathrm{AM}$ to 4 PM P.S.T.}

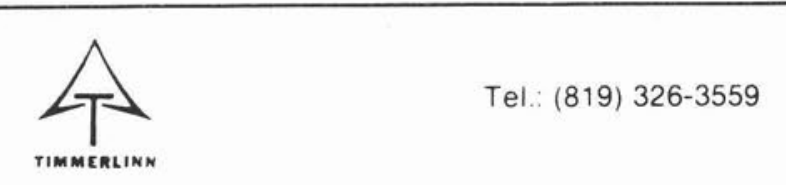

\title{
TIMMERLINN LMMreE
}

PROFESSIONAL AND TECHNICAL SERVICES

IN FORESTRY AND ENVIRONMENTAL SCIENCES

R.R. No. 2, STE. AGATHE DES MONTS, QUE. J8C $2 Z 8$

\section{Journal Bargains for Institute Members}

The Table of Contents of the Canadian Journal of Forest Research is carried regularly in the Forestry Chronicle. Members are reminded that this prestigious forest research publication is available to them at a special price of $\$ 36.00$ per year, plus $\$ 2.52$ for Goods and Services Tax. The normal rate for individual subscribers to the journal direct from National Research Council is $\$ 82.00$. All NRC journals are available to members at greatly reduced prices. Send orders with payment to the national office.

\section{Woodlot Service (1978) Ltd.}

"All Matters Pertaining to Forestry"

\author{
GORDON B. YOUNG, B.Sc.F., M.F. \\ Registered Professional Forester
}

320 Maple Street

Bus.: 506-458-9366

Fredericton, N.B. E3A 3R4

Home: 506-472-7721 